\title{
Truncated TALE-FP as DNA Staining Dye in a High-salt Buffer
}

\author{
Eunji Shin ${ }^{1,3}$, Woojung Kim ${ }^{1,3}$, Seonghyun Lee ${ }^{1}$, Jaeyoung Bae ${ }^{1}$, Sanggil Kim ${ }^{1}$, Wooseok Ko ${ }^{1}$, \\ Ho Seong Seo $\mathbb{D}^{2}$, Sangyong Lim $\left(\mathbb{1}^{2}\right.$, Hyun Soo Lee $\mathbb{1}^{1 *}$ \& Kyubong Jo ${ }^{1^{*}}$
}

Large DNA molecules are a promising platform for in vitro single-molecule biochemical analysis to investigate DNA-protein interactions by fluorescence microscopy. For many studies, intercalating fluorescent dyes have been primary DNA staining reagents, but they often cause photo-induced DNA breakage as well as structural deformation. As a solution, we previously developed several fluorescentprotein DNA-binding peptides or proteins (FP-DBP) for reversibly staining DNA molecules without structural deformation or photo-induced damage. However, they cannot stain DNA in a condition similar to a physiological salt concentration that most biochemical reactions require. Given these concerns, here we developed a salt-tolerant FP-DBP: truncated transcription activator-like effector (tTALE-FP), which can stain DNA up to $100 \mathrm{mM} \mathrm{NaCl}$. Moreover, we found an interesting phenomenon that the tTALE-FP stained DNA evenly in $1 \times$ TE buffer but showed AT-rich specific patterns from $40 \mathrm{mM}$ to $100 \mathrm{mM} \mathrm{NaCl}$. Using an assay based on fluorescence resonance energy transfer, we demonstrated that this binding pattern is caused by a higher DNA binding affinity of tTALE-FP for AT-rich compared to GC-rich regions. Finally, we used tTALE-FP in a single molecule fluorescence assay to monitor real-time restriction enzyme digestion of single DNA molecules. Altogether, our results demonstrate that this protein can provide a useful alternative as a DNA stain over intercalators.

Large DNA molecules have been a versatile platform to investigate a variety of genomic, epigenetic, biochemical, and biophysical studies ${ }^{1}$. For genome analysis, Optical Mapping and nanocoding have been representative single-molecule analytical systems to obtain DNA physical maps ${ }^{2-6}$. They have been applied for many genome projects to aid genome assembly with sequencing ${ }^{7,8}$, as well as to reveal large scale structural variations of the genome ${ }^{9,10}$. Single-molecule DNA maps have also been utilized for the rapid identification of DNA molecules without sequencing ${ }^{11,12}$. Alternatively, elongated DNA molecules provide a platform to visualize biochemical information, such as chemical modifications ${ }^{13,14}$ and DNA damage at the single-molecule level ${ }^{15-18}$. There have been many studies conducted to monitor enzymatic motions and functions on a large elongated DNA molecule, such as the dynamics of DNA replication forks ${ }^{19,20}$, the movement of DNA translocases ${ }^{21}$, and the role of polymerase subunits ${ }^{22}$.

Most of those studies have commonly used intercalating fluorescent dyes such as YOYO- ${ }^{23}$, SYTOX, and $\mathrm{SYBR}^{24}$. However, these organic dyes present major drawbacks for staining DNA molecules ${ }^{25}$. For example, their intercalation into DNA induces photodamage under continuous laser illumination through the formation of radical intermediates that create single-, or double-stranded breaks in DNA molecules ${ }^{26,27}$. This intercalation also alters the structure and mechanical properties of $\mathrm{DNA}^{28}$, which can perturb enzymatic reactions on a DNA molecule, in bulk reactions ${ }^{29-31}$, as well as at the single-molecule level ${ }^{32,33}$.

As a solution, we have previously reported the development of FP-tagged DNA-binding peptides (FP-DBPs) as new staining reagents ${ }^{25,34-36}$. FP-DBPs do not cause photo-induced DNA cleavage or structural deformation. Moreover, it is possible to control DNA staining reversibly by the $\mathrm{pH}$ shift or adjusting salt concentration. This feature allows DNA molecules to be monitored as follows: DNA staining, destaining, biochemical reaction, and another staining to watch the result of the reaction. However, some scientists personally asked whether it is possible to stain DNA with FP-DBP in their reaction buffers that contain a salt concentration similar to a physiological condition, such as phosphate-buffered saline (PBS). Unfortunately, we found that FP-DBPs reported so far were not compatible with these reaction buffers.

\footnotetext{
${ }^{1}$ Department of Chemistry and Interdisciplinary Program of Integrated Biotech, Sogang University, 1 Shinsudong, Mapogu, Seoul, 04107, Korea. ${ }^{2}$ Research Division for Biotechnology, Korea Atomic Energy Research Institute, Jeongeup, 580-185, Korea. ${ }^{3}$ These authors contributed equally: Eunji Shin and Woojung Kim. *email: hslee76@ sogang.ac.kr; jokyubong@sogang.ac.kr
} 
A

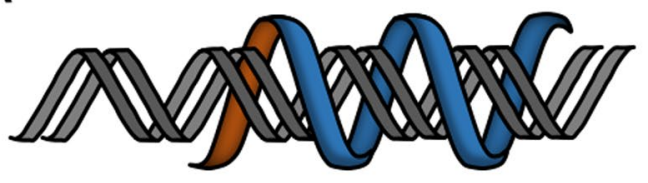

Conventional TALE protein

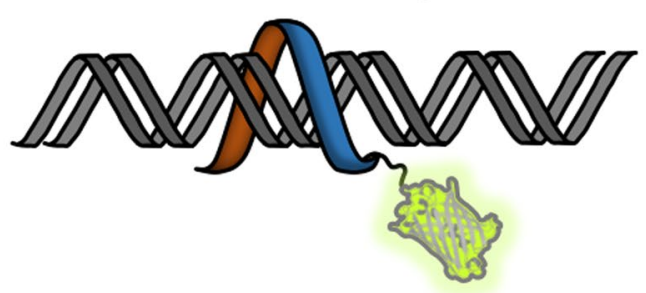

tTALE-FP

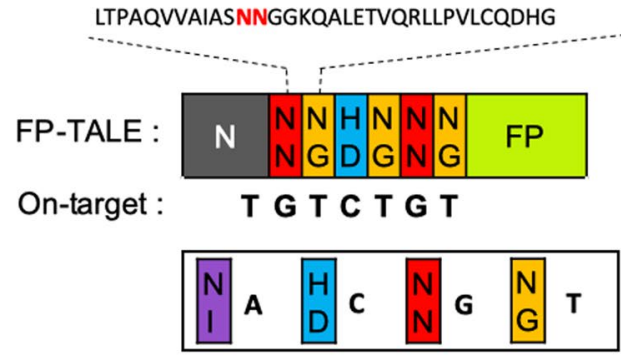

B

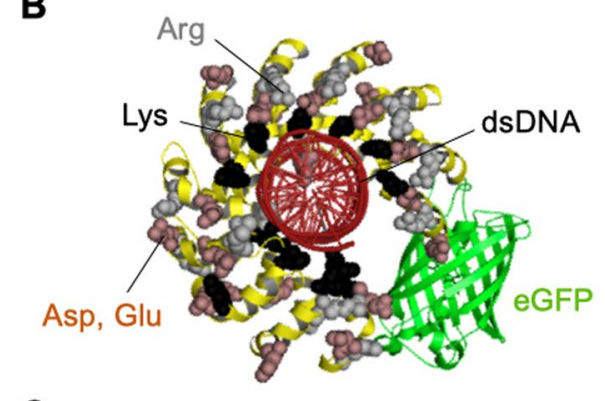

C

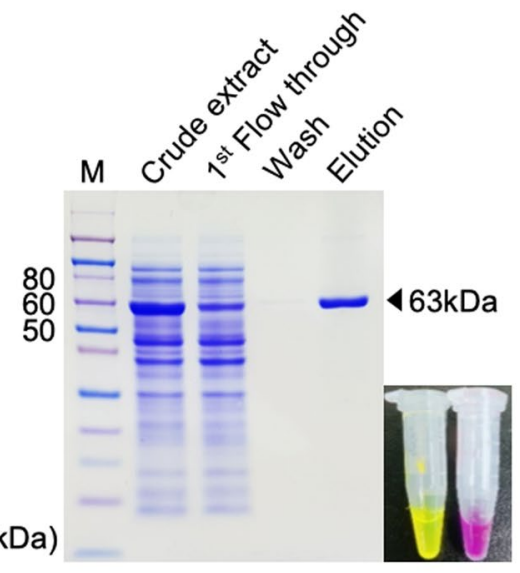

D

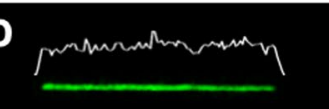

tTALE
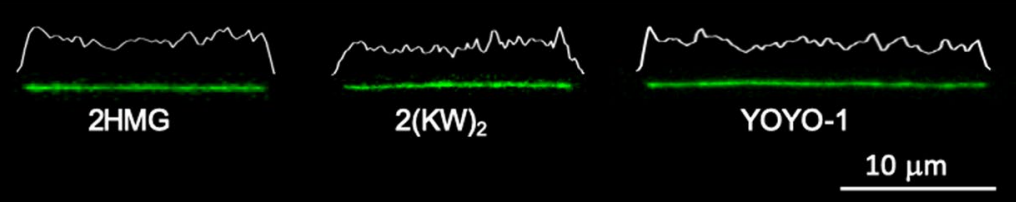

Figure 1. Truncated TALE-FP. (A) Illustration of conventional TALE on DNA and binding domains designed to recognize 7-mer 'TGTCTGT' fused with FP. (B) The combined structure of tTALE-FP and DNA. (C) SDSPAGE for affinity chromatography purification of TALE-eGFP $(63 \mathrm{kDa})$. Purified tTALE-eGFP and tTALEmCherry. (D) Fluorescence microscopic images and intensity profiles for tTALE-eGFP $(2 \mathrm{nM})$ stained $\lambda$ DNA molecule $(48.5 \mathrm{~kb})$ compared with $2 \mathrm{HMG}-\mathrm{eGFP}^{34}, 2(\mathrm{KW})_{2}$ - $\mathrm{eGFP}^{25}$, and YOYO-1 stained ones.

To overcome the issue of salt-tolerance, we attempted to develop a novel FP-DBP using a gene of transcription activator-like effector (TALE). TALE-FP has been used for various applications to visualize their interactions with DNA within the cell nucleus ${ }^{37,38}$. Besides, TALE linked to a nuclease domain (TALEN) is one of the well-known genome-editing tools ${ }^{39}$. From these previous studies, we noticed that TALE-FP and TALEN are capable of binding DNA within a cell nucleus that generally contains relatively high-salt concentrations. For example, a previous paper reported the salt concentration of $150 \mathrm{mM} \mathrm{NaCl}$ and $260 \mathrm{mM} \mathrm{KCl}$ in a cell nucleus ${ }^{40}$. Accordingly, TALE-FP can be a promising candidate for staining DNA in a high-salt solution.

We added an FP gene at the C-terminus of the 7-mer DNA binding domain from a 20-mer target sequence TALEN gene ${ }^{41}$. As expected, this short-length truncated TALE-FP (tTALE-FP) showed salt-tolerant DNA staining capability. More specifically, this protein stained DNA evenly in Tris-EDTA buffer $(1 \times \mathrm{TE})$. The increase of $\mathrm{NaCl}$ concentration preserved tTALE-FPs at AT-rich regions up to $100 \mathrm{mM} \mathrm{NaCl}$, while it removed them from GC-rich ones above $40 \mathrm{mM} \mathrm{NaCl}$. We attempted to explain this intriguing property by fluorescence resonance energy transfer (FRET). Besides, tTALE-FP shared the advantages that other FP-DBPs had, such as no photo-cleavage or no structural deformation, and reversible staining ${ }^{25}$. Finally, we demonstrated the power of the tTALE-FP for the visualization of real-time restriction enzyme digestion reactions on single-molecule DNA by comparing it with the YOYO-1 stained DNA molecule.

\section{Results and Discussion}

Truncated transcription-activator-like effectors - fluorescent proteins (tTALE-FP). Figure 1 illustrated a novel FP-DBP constructed from the gene of a transcription activator-like effector nuclease for a 20 -mer target sequence (TGTCTGTGGCCTGGTGCCTG) ${ }^{41}$. TALE has three domains: N-terminal, DNA binding repeat, and $\mathrm{C}$-terminal ${ }^{42}$. The $\mathrm{N}$-terminal consists of 133 amino acids that bind thymine ${ }^{43}$. We added an FP gene at the C-terminus of 7-mer (TGTCTGT) DNA binding domain gene. A reason to make 7-mer tTALE-FP was that there are eight target sites in the $\lambda$ DNA, while there are two sites for 8-mer, one for 9-mer, and none for 10 -mer or larger. We did not include TALE's C-terminal domain because it contains a transcriptional activation 
domain and a nuclear localization signal ${ }^{41}$. Each DNA binding repeat domain comprises 34 or 35 amino acids, and the 12th and 13th amino acids per repeat, which determine the base specificity, called repeat variable di-residues (RVDs) (Fig. 1A) ${ }^{44}$. On the other hand, it is controversial to predict an RVD's binding base. According to Boch et al., the NN in TALE RVD has a similar preference for $\mathrm{G}$ and $\mathrm{A}^{45}$. However, Miller et al. reported a further study that the $\mathrm{NN}$ has a higher binding affinity for $\mathrm{G}$ than $\mathrm{A}^{46}$. Moreover, they proved that neighboring repeats also influence specificity. Their result suggests that NG-NN-NG has a base specificity for T-G-T. Therefore, we used TGTCTGT as the target sequence in the remaining part of this paper (Fig. 1A).

TALE's combined structure is a right-handed superhelix that wraps around the double-stranded DNA molecule $^{47}$. Figure 1B shows a molecular model that predicts three-quarter wrapping of the double helix, which we generated by using PyMol from a combination of data for TALE ${ }^{48}$, eGFP ${ }^{49}$, and a complex of TALE and DNA ${ }^{47}$. The predicted structure shows lysine residues primarily in the inside of the superhelix. They may contribute to the electrostatic interaction with the DNA phosphate backbone. The outside structure seems neutral or slightly negatively charged due to the combination of arginine, aspartate, and glutamate, which implies that its protein surface interacts weakly with negatively charged DNA backbones.

We prepared tTALE-eGFP and tTALE-mCherry (Fig. 1C). Figure 1D demonstrated tTALE-FP stained $\lambda$ DNA molecules in $1 \times$ TE buffer ( $10 \mathrm{mM}$ Tris, $1 \mathrm{mM}$ EDTA, $\mathrm{pH}$ 8.0), compared with other staining reagents, such as 2(KWKWKKA)-eGFP ${ }^{25}, 2 \mathrm{HMG}-\mathrm{eGFP}^{34}$, and YOYO-1. For these images, we elongated DNA molecules by a droplet-spreading protocol in which a drop of DNA solution is placed on a positively-charged coverslip. A subsequent quick covering with a second glass slide then induces a local flow, which results in the DNA collapsing to the surface in an extended conformation. The average extension of the tTALE-FP stained $\lambda$ DNA molecule was with a length of $15 \mu \mathrm{m}$ similar to other FP-DBPs (2HMG-eGFP and 2(KWKWKKA)-eGFP), while the YOYO-1 stained DNA showed a greatly increased length of $21.5 \mu \mathrm{m}$. Given that the expected length of a fully-extended $\lambda$ DNA is about $16.3 \mu \mathrm{m}$, this demonstrates that tTALE-FP does not significantly distort the native DNA structure, whereas YOYO- 1 binding induces significant lengthening ${ }^{50}$.

Salt-dependence of tTALE-FP stained $\lambda$ DNA molecules. The primary motivation of this study is to develop a salt-tolerant FP-DBP. Thus, we compared the two extreme cases of low and high-salt concentrations, such as $1 \times$ TE and PBS. $1 \times$ TE buffer has $10 \mathrm{mM}$ Tris and $1 \mathrm{mM}$ EDTA. Since Tris-H is a weak acid, the ionic strength should be less than $10 \mathrm{mM}$ at $\mathrm{pH} 8.0$ by considering their $\mathrm{pKa}$ values. Previously, we determined $5.26 \mathrm{mM}$ as the ionic strength in a $1 \times$ TE buffer solution ${ }^{50}$. On the other hand, phosphate-buffered saline (PBS) contains a high concentration of salts $\left(137 \mathrm{mM} \mathrm{NaCl}, 2.7 \mathrm{mM} \mathrm{KCl}, 10 \mathrm{mM} \mathrm{Na}_{2} \mathrm{HPO}_{4}, 1.8 \mathrm{mM} \mathrm{KH}_{2} \mathrm{PO}_{4}\right)$. In contrast to Fig. 2 A $(1 \times$ TE), Fig. $2 B(1 \times$ PBS $)$ shows no DNA molecules except scattered spots. Next, we gradually increased $\mathrm{NaCl}$ concentrations into $1 \times \mathrm{TE}$ buffer, which revealed characteristic patterns for $\lambda$ DNA molecule ranging from $40 \mathrm{mM}$ to $100 \mathrm{mM}$ (Fig. 2C). For larger than $100 \mathrm{mM} \mathrm{NaCl}$, images were similar to the case of $1 \times \mathrm{PBS}$ buffer.

Interestingly, $\lambda$ DNA images from $40 \mathrm{mM}$ to $100 \mathrm{mM}$ have consistent patterns that seem related to the A/T frequency in silico map (Fig. 2C). This pattern is similar to previous results of AT-specific polypyrrole compound ${ }^{6}$ and FP-DBPs of $\mathrm{H}-\mathrm{NS}$ and $\mathrm{HMG}^{11}$. This pattern is even retained in concatenated $\lambda$-DNA molecules, which allows us to readily identify the number of monomers and their orientation (Fig. 2D). However, it required further characterization of why tTALE-FP generated the AT-specific pattern. We note that TTALE-FP has been designed to show preferred binding to seven nucleotides target sequence (TGTCTGT). While this does not match with the observed staining pattern shown in Fig. 2C, we cannot conclude that therefore, target binding is absent. Instead, it just means that the overall DNA affinity of the protein might be too high to resolve this binding. To be more quantitative, we designed a bulk assay to measure tTALE-FP's binding affinity to target, AT-rich, and GC-rich sequences, respectively.

The binding affinity of tTALE-eGFP by FRET assay and single-molecule assay. We designed a fluorescence resonance energy transfer (FRET) assay to measure the binding affinity of tTALE-eGFP to double-stranded DNA oligomers labeled with ATTO-590, which followed our previous paper ${ }^{51}$. Fig. 3A illustrates how a significant FRET emission occurs between tTALE-FP and DNA. Figure 3B presents a typical intensity changes: the increase of ATTO-590 emission at $630 \mathrm{~nm}$ and the decrease of tTALE-eGFP emission at $510 \mathrm{~nm}$. To characterize sequence-specificity, we prepared three types of ATTO-590 labeled DNA oligomers: TGTCTGTATG as the target sequence, GAAGAAAATGATCTA as AT-rich one, and GCGACCTCGCGGGTT as GC-rich one. We designed AT-rich and GC-rich sequences from the $\lambda$ genome. First, the FRET assay allowed us to measure the dissociation constant $\left(K_{\mathrm{d}}=26.7 \mathrm{nM}\right)$ of tTALE-eGFP and the target sequence in $1 \times \mathrm{TE}$ (Fig. 3C). This value is much lower than other FP-DBPs such as $14.6 \mu \mathrm{M}$ for $2(\mathrm{KW})_{2}-\mathrm{eGFP}^{25}$, and $586 \mathrm{nM}$ for $2 \mathrm{HMG}$-eGFP ${ }^{34}$. Fig. 3D demonstrates that the increase of $\mathrm{NaCl}$ concentrations reduces FRET intensities with different decreasing trends for three DNA oligomers. More specifically, for $20 \mathrm{mM}$ or lower $\mathrm{NaCl}$ concentrations, the data from three oligomers are similar within the error range in an unsaturated protein condition (tTALE-FP: $30 \mathrm{nM}$ ). From $40 \mathrm{mM}$ to $150 \mathrm{mM} \mathrm{NaCl}, \mathrm{GC}$-rich data are significantly lower than the others, which implies that the GC-rich sequence has a weak affinity for tTALE-FP. This result explains AT-specific patterns of $\lambda$ DNA that we observed in Fig. $2 B$. Notably, the target sequence shows higher FRET efficiency than the others from $150 \mathrm{mM}$ to $200 \mathrm{mM}$.

Besides, we conducted a single-molecule assay by using tTALE-eGFP stained $\lambda$ DNA (Fig. 3E). First, we loaded unstained $\lambda$ DNA solution on a positively charged surface within a flow cell and flushed tTALE-eGFP of given concentrations $(2 \sim 64 \mathrm{nM})$. Then we flushed out unbound FP with $10 \mu \mathrm{L}$ of $1 \times \mathrm{TE}$ buffer. We analyzed the integrated intensity of individual molecules using a lab-made python program. Figure $3 \mathrm{~F}$ shows a typical protein-DNA binding curve based on Hill's equation. Nevertheless, it is challenging to define $K_{\mathrm{d}}$ because of unknown the number of FP on DNA $(n)$. 


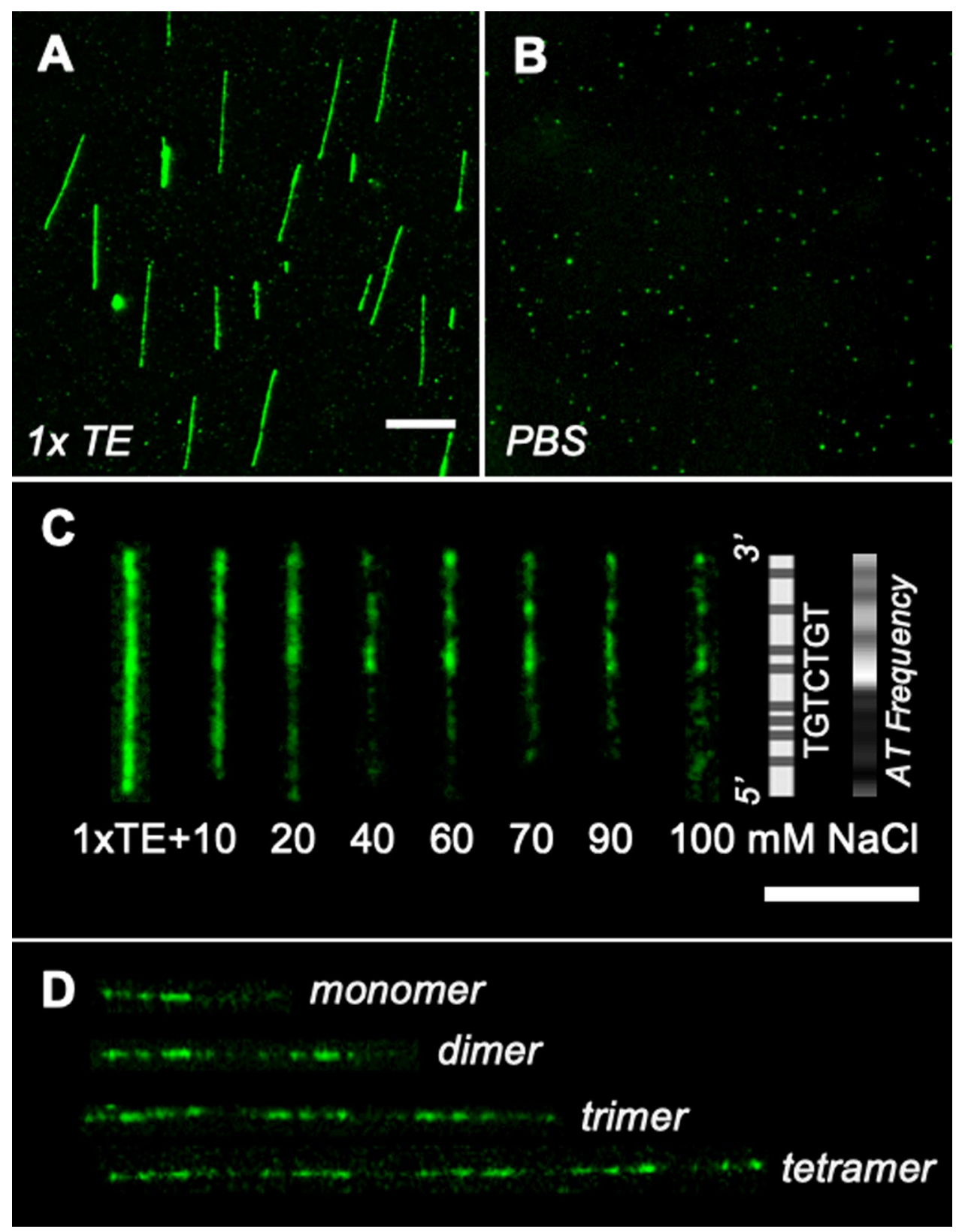

Figure 2. Salt-dependence of tTALE-FP staining. (A) $1 \times$ TE (Tris-EDTA: $10 \mathrm{mM}$ Tris, $1 \mathrm{mM}$ EDTA, pH 8.0). (B) $1 \times$ PBS (phosphate-buffered saline: $137 \mathrm{mM} \mathrm{NaCl}, 2.7 \mathrm{mM} \mathrm{KCl}, 10 \mathrm{mM} \mathrm{Na}_{2} \mathrm{HPO}_{4}, 1.8 \mathrm{mM} \mathrm{KH}_{2} \mathrm{PO}_{4}, \mathrm{pH}$ 7.4). (C) $\lambda$ DNA molecules after the addition of $\mathrm{NaCl}(10-100 \mathrm{mM})$ to $1 \times \mathrm{TE}$ buffer. Sequence-specific in silico maps of TGTCTGT and AT frequency. Scale bar $=10 \mu \mathrm{m}$. (D) $\lambda$ concatemers in $40 \mathrm{mM} \mathrm{NaCl}$ added $1 \times \mathrm{TE}$ (i.e., tetramer $=4 \times 48.5 \mathrm{~kb}=194 \mathrm{~kb}$ ). All DNA molecules are stained by preincubation in $2 \mathrm{nM}$ tTALE-FP.

$$
K_{d}=\frac{[D N A][\text { protein }]^{n}}{[D N A-n \times \text { protein }]}
$$

Roughly, it is possible to assume $n=1$ and [DNA] as the concentration of binding sites, which suggests that a protein concentration corresponds to $K_{\mathrm{d}}$ when the intensity equal to half of the maximum intensity. This assumption predicts $K_{\mathrm{d}}=22 \mathrm{nM}$ from Fig. $3 \mathrm{~F}$, which agrees roughly with $K_{\mathrm{d}}=26.7 \mathrm{nM}$ that we measured in the FRET bulk assay. However, we found that surface-immobilized DNA molecules were not efficient for staining and destaining. Therefore, we could not see DNA with $8 \mathrm{nM}$ or lower tTALE-eGFP, while we used $2 \mathrm{nM}$ for other preincubation results. Moreover, we observed randomly destained patterns instead of the AT-specific pattern when we flushed the flow cell with a $\mathrm{NaCl}$ solution. Therefore, for the next experiment, we preincubated DNA with tTALE-FP in a test-tube before loading into a positively-charged surface. 
A
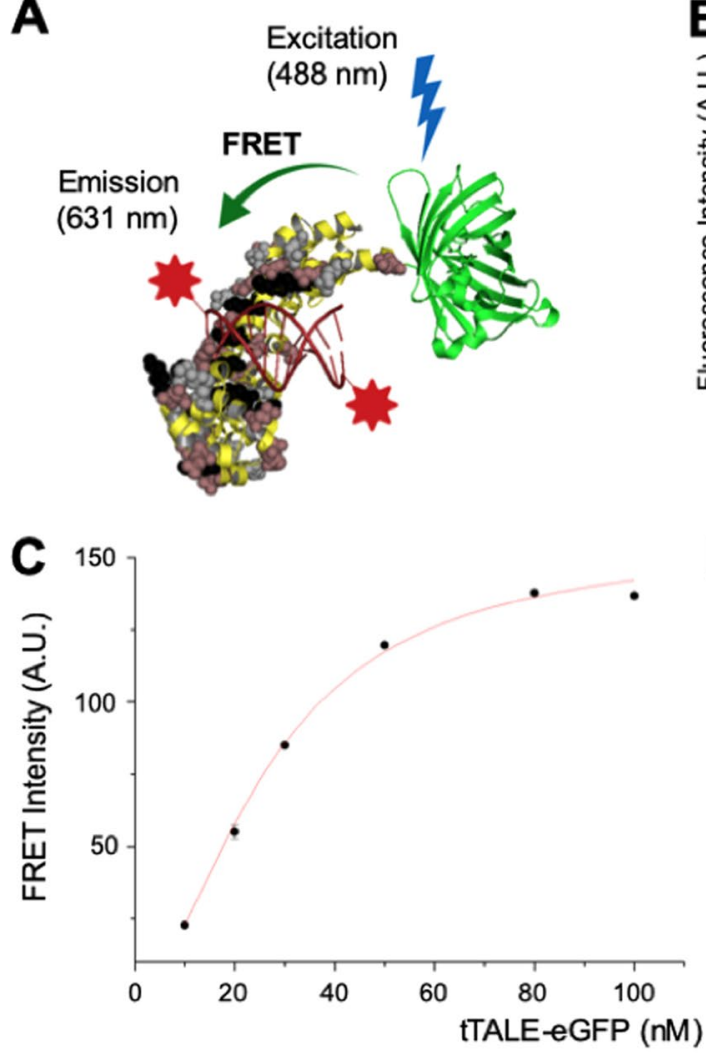

$\mathbf{E}$

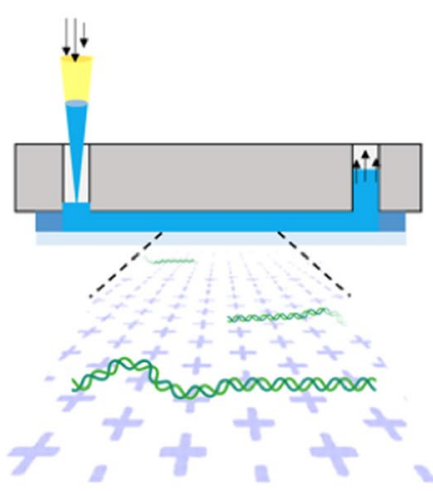

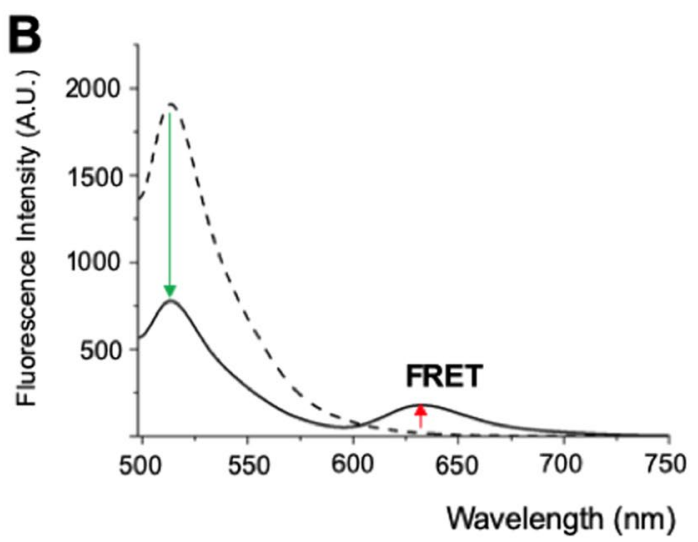
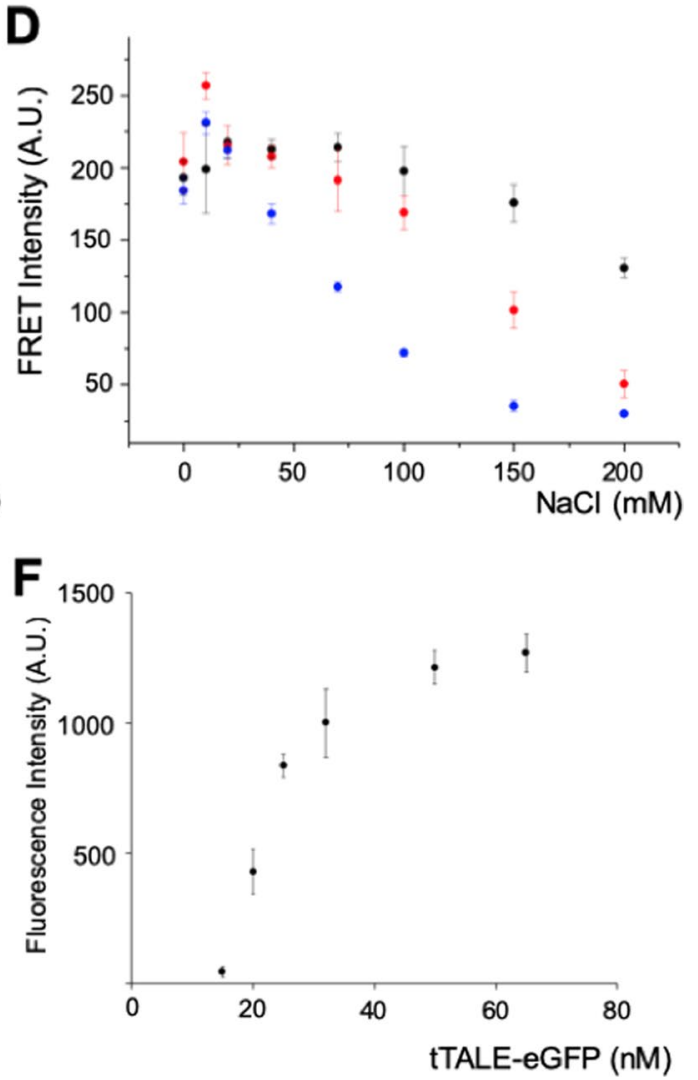

Figure 3. Quantitative analysis with FRET and flow cell with surface-immobilization for the binding affinity of tTALE-eGFP on DNA molecules. (A) Schematics of FRET between tTALE-eGFP and ATTO-590 labeled DNA molecules. (B) Emission spectra from the $30 \mathrm{nM}$ tTALE-eGFP only (dotted line) and the 30/100 nM complex of tTALE-eGFP/5'-ATTO-590 labeled-target sequence (solid line). (C) Fluorescence intensity measurement of tTALE-FP with 1 pM 5'-ATTO-590 labeled-target dsDNA oligomer at $631 \mathrm{~nm}$. $K_{\mathrm{d}}=26.7 \mathrm{nM}$. (D) Change of fluorescence intensity of 30/100 nM tTALE-eGFP/5'-ATTO-590 labeled dsDNA oligomers at $631 \mathrm{~nm}$ with $\mathrm{NaCl}$ concentration. $\bullet$ : target DNA. $\bullet$ : AT-rich DNA. $\bullet$ : GC-rich DNA. (E) Schematics of the flow cell with surfaceimmobilization (made in $\odot$ BioRender - biorender.com). (F) tTALE-eGFP concentration-dependent fluorescence intensities of $\lambda$ DNA. (see Materials and Methods for more details).

Surface-immobilized tTALE-FP stained DNA with the AT-specific pattern. Figure 4 A shows $2 \mathrm{nM}$ tTALE-FP stained $\lambda$ DNA molecules immobilized on a positively charged surface after preincubation in a $70 \mathrm{mM}$ $\mathrm{NaCl}$ concentration. This AT-specific staining is useful because it can tell the orientation of the $\lambda$ genome, as indicated by the white arrows. To quantitatively evaluate the consistency of the tTALE-FP DNA staining, we calculated the Pearson cross-correlation coefficient $(c c)$ among molecular images using a lab-made Python program, which was available on the website for our previous paper ${ }^{6}$. The $c c$ value was $0.91 \pm 0.032$, which suggests that molecular patterns are consistent and reproducible (Fig. 4B).

Alternatively, we made the consensus intensity pattern by combining molecular intensity profiles $(i)$, which were compared with in silico AT-frequency map for $\lambda$ DNA molecules (ii). Figure 4C compares the fluorescence intensity profiles for $(i)$ and (ii) with $c c=0.86$. This comparison for the two intensity graphs demonstrates that 

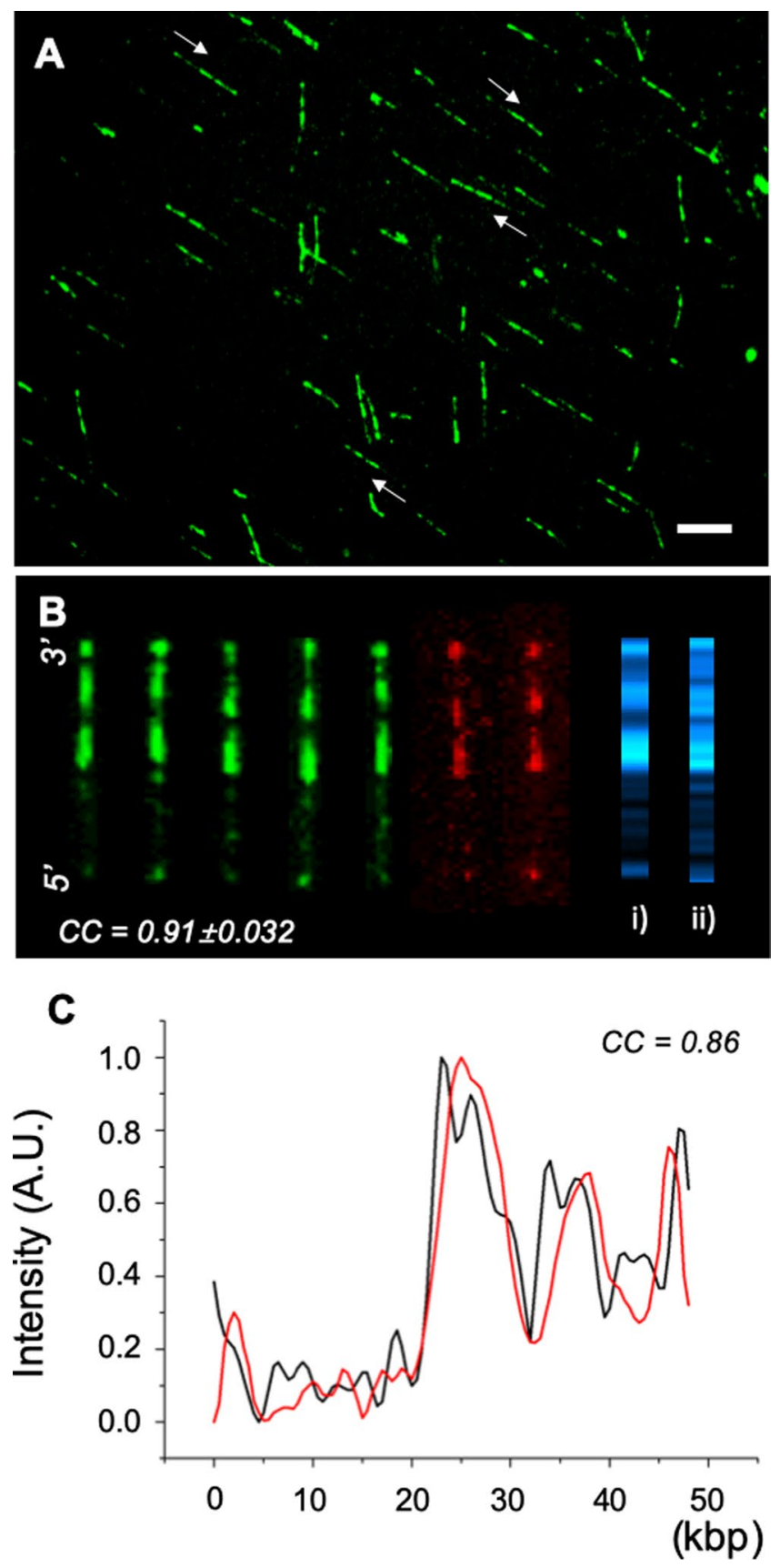

Figure 4. tTALE-FP stained $\lambda$ DNA molecules immobilized on a positively charged surface in $70 \mathrm{mM} \mathrm{NaCl}$. (A) Fluorescence micrographs of surface-immobilized AT-specific patterned DNA molecules with stained by preincubation in $2 \mathrm{nM}$ tTALE-FP without flushing unbound tTALE-FP. The white arrows indicate the molecular direction of $\lambda$ DNA (scale bar $=10 \mu \mathrm{m}$ ). (B) Aligned $\lambda$ DNA, eGFP (green) and mCherry (red). $c c=0.91 \pm 0.032$ among molecules. (i) Consensus map. (ii) AT-frequency in silico map. (C) Comparison of consensus map (red) and AT-frequency in silico map (black). $c c=0.86$.

tTALE-FP produces DNA staining patterns, which show a good correlation with AT-rich sequences, even though it cannot resolve highly detailed sequence features.

Flow-cell tethered DNA molecules reversibly stained with tTALE-FP. Figure 5 demonstrates the application of tTALE-FP to tethered DNA via biotin-avidin interaction in a flow cell ${ }^{35}$. The approach of surface-tethered DNA elongated by a flow has advantages over surface-immobilization because there is only a single attachment point. In contrast, surface-immobilization will result in many contact points and thus could significantly affect protein activity, as shown in Fig. $3 \mathrm{E}, \mathrm{F}^{52}$. Moreover, this approach does not need preincubation in a test tube. We tethered DNA molecules first, loaded tTALE-FP, and then flushed with $1 \times$ TE solution to elongate DNA. The elongation length of the tethered tTALE-FP-stained $\lambda$ DNA in the flow cell was $13.44 \pm 0.38 \mu \mathrm{m}$, 

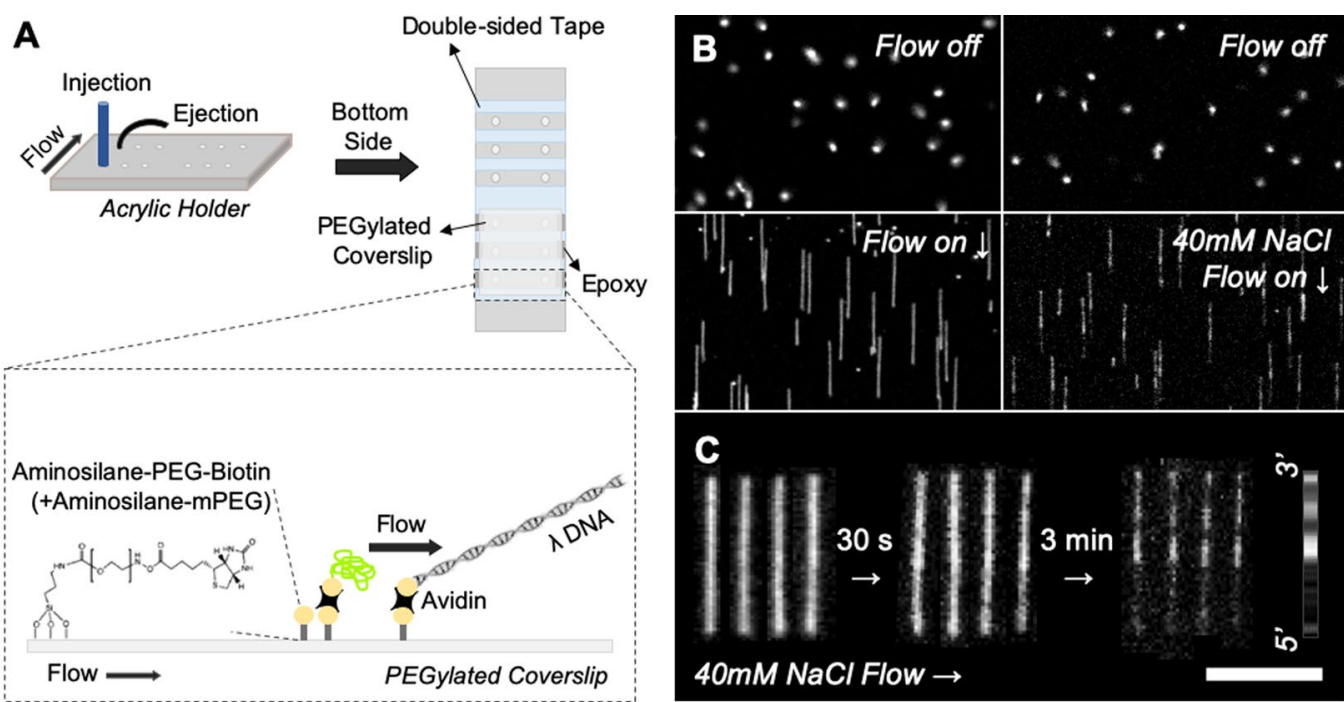

D

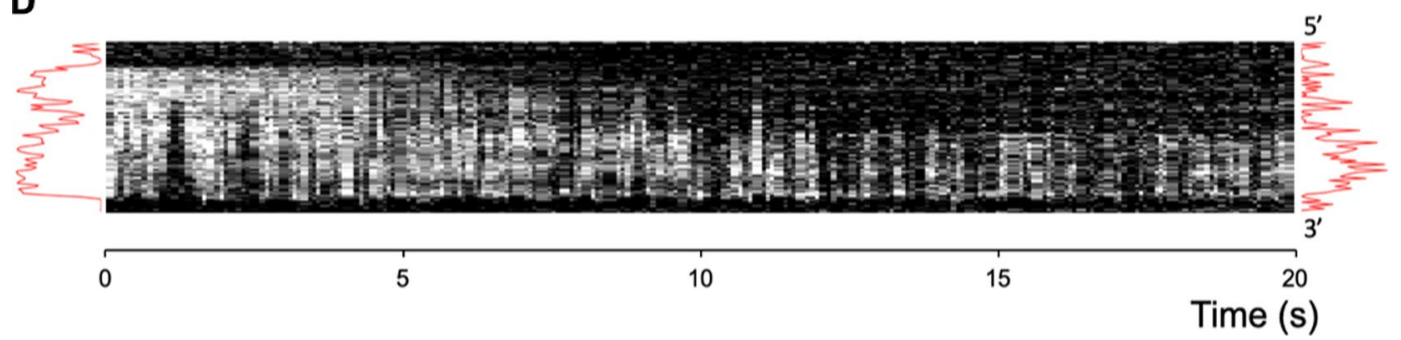

Figure 5. Tethered $\lambda$ DNA reversibly stained with tTALE-FP in a flow chamber. (A) Schematics of DNA tethering in a flow cell. (B) Fluorescence microscopic images of tethered $\lambda$ DNA molecules with mushroom-like coiled conformation (flow-off) and elongated one (flow-on). The experiment steps were DNA tethering, $2 \mathrm{nM}$ tTALE-FP loading, and flushing with $1 \times \mathrm{TE}$ or $40 \mathrm{mM} \mathrm{NaCl}$ added solutions. (C) Time-lapse images following the addition of $40 \mathrm{mM} \mathrm{NaCl}$ solution to reveal the AT-specific pattern in a flow cell with the consensus pattern from Fig. 4B. Scale bar $=10 \mu \mathrm{m}$. (D) The kymogram represents a 20-sec destaining process of tTALE-FP from $\lambda$ DNA in $70 \mathrm{mM} \mathrm{NaCl}$ solution (see Movie S1).

representing $83 \%$ of the full contour length of native $\lambda$ DNA $(16.3 \mu \mathrm{m}=0.337 \mathrm{~nm} \times 48,502 \mathrm{bp})$, at a flow rate of $100 \mu \mathrm{L} / \mathrm{min}$. This length is consistent with other FP-DBP results that range from $13.4 \mu \mathrm{m}(82 \%)$ to $14.6 \mu \mathrm{m}(89 \%)$ as well as our previous simulation result that predicted $83 \%$ in stretching the same flow cell ${ }^{34}$.

Figure 5C,D present the destaining process in a salt solution. $40 \mathrm{mM} \mathrm{NaCl}$ added $1 \times \mathrm{TE}$ buffer solution gradually revealed AT-specific patterns, which agreed with the surface-immobilized DNA pattern in Fig. 4B. More specifically, the tTALE-FP staining of the $\lambda$ DNA molecules were homogeneous in the beginning, and after 30 seconds of adding a $40 \mathrm{mM} \mathrm{NaCl}$ solution into the flow cell, these fluorescent proteins started to fall off and revealed the AT-specific pattern in three minutes. We attempted to make a movie for Fig. $5 \mathrm{C}$, but it was challenging because a continuous illumination for three minutes caused severe bleaching on DNA images. In order to reduce the effects of bleaching, we sped up the destaining process by switching to a buffer containing $70 \mathrm{mM}$ $\mathrm{NaCl}$. Therefore, we enhanced $\mathrm{NaCl}$ concentration to $70 \mathrm{mM}$ to destain quickly for 20 seconds without bleaching (Fig. 5D). Although the pattern does not agree perfectly well with the AT-specific intensity profile, this kymogram demonstrates the destaining process in the GC-rich region $\left(5^{\prime}\right)$.

Real-time observation of tTALE-FP staining. Next, we attempted to observe the tTALE-FP staining process in real-time. For this purpose, we first stained tethered $\lambda$ DNA with tTALE-FP to set up the focal position in the microscope. Then, we removed tTALE-FP with $150 \mathrm{mM} \mathrm{NaCl}$ added $1 \times \mathrm{TE}$ and subsequent washing with a $1 \times$ TE buffer solution. After a while, we loaded $2 \mathrm{nM}$ tTALE-FP in $1 \times$ TE. Figure $6 \mathrm{~A}$ presents a kymogram of the staining process for 60 seconds. Figure $6 \mathrm{~B}$ shows fluorescent intensity profiles from the kymogram to show two intensity changes for AT-rich (red) and GC-rich (blue) regions over time. For the first 20 seconds, staining increased with similar rates for both, but the AT-rich sequence was stained preferentially over the GC-rich one from 20 to 50 seconds. However, intensity gaps between the two parts became narrowed at 60 seconds. Figure $6 \mathrm{C}$ illustrates the change of fluorescent intensity profiles along the genome $\left(5^{\prime} \rightarrow 3^{\prime}\right)$. The 40 -second profile shows that the GC-rich region $\left(5^{\prime}\right)$ has a lower intensity than the AT-rich one $\left(3^{\prime}\right)$, but the 60 -second intensity profile shows that the staining becomes more uniform along the $\lambda$ genome.

Real-time monitoring of restriction-enzyme reaction with tTALE-FP vs. YOYO-1. Figure 7 illustrates real-time monitoring of restriction enzyme reactions on tethered DNA in a flow cell (see SI Movies S3, 

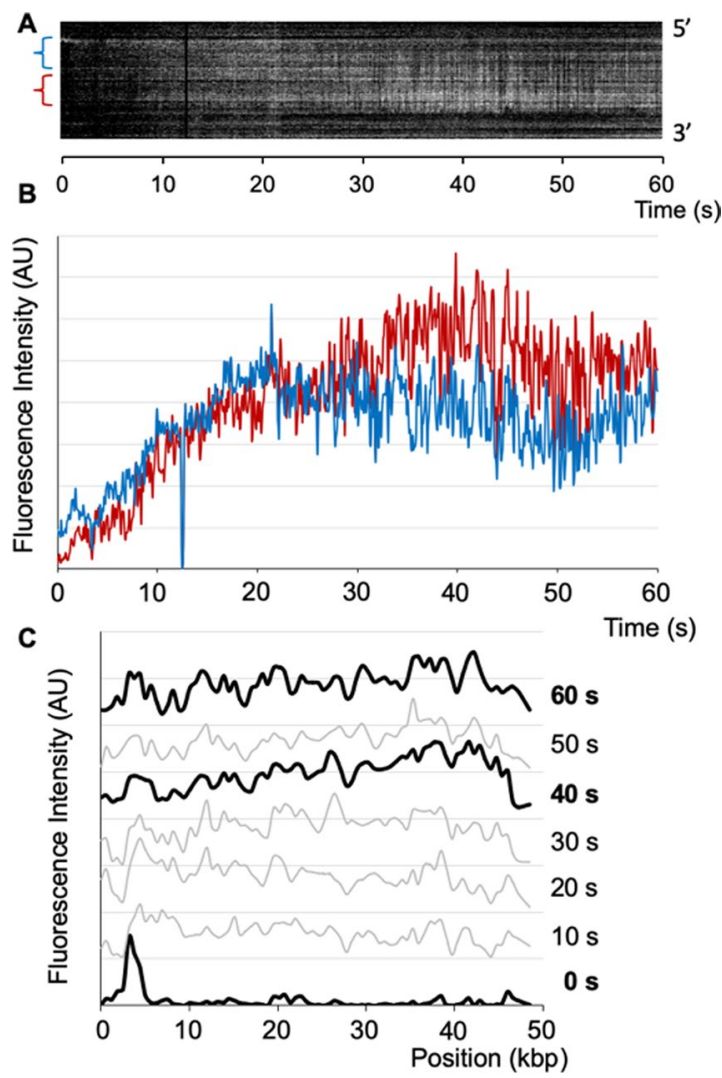

Figure 6. Real-time observation of $\lambda$ DNA staining with tTALE-FP. (A) Kymogram of $\lambda$ DNA staining with tTALE-FP $(2 \mathrm{nM})$ in a $1 \times$ TE buffer. Each blue and red bracket represents the GC-rich and the AT-rich regions, respectively. (B) Fluorescence intensity profiles over time for the GC-rich (blue) and the AT-rich (red) regions of tTALE-FP stained $\lambda$ DNA. (C) Fluorescence intensity along $\lambda$ DNA $\left(5^{\prime} \rightarrow 3^{\prime}\right)$ at each 10 -sec interval (see Movie S2).

S4, and S5). On the fully stretched $\lambda$ DNA, the XhoI enzyme (CTCGAG), a single cutter of $\lambda$ DNA (33.5 kb and $15.0 \mathrm{~kb}$ ), created digested fragments that move through the microscopic view in the movie (see SI Movie S3). After 31.6 seconds, there were many digested DNA fragments of $15 \mathrm{~kb}(3.8 \mu \mathrm{m})$ tethered on the surface (Fig. 7A).

As a comparison, we performed an EcoRI restriction enzyme reaction using YOYO-1 stained DNA (Fig. 7B and SI Movie S4). Right after introducing the enzyme, most DNA molecules entirely disappeared instead of sequence-specific digestions. A couple of previous studies reported the inhibition of TOTO-1 and YOYO-1 against endonuclease activity to cut $\mathrm{DNA}^{29,30}$. There was another study to visualize endonuclease digestion of TOTO-1 stained DNA in a nanochannel, in which they reduced TOTO-1 concentration down to 1 dye: $20 \mathrm{bp}$ while 1 dye: $4 \mathrm{bp}$ is a typical concentration ${ }^{53}$. Therefore, we could not expect proper digestion by YOYO-1stained DNA, but Fig. 7B was still an unexpected result. As a control, we applied restriction enzyme digestion buffer (NEB CutSmart) to YOYO-1 stained $\lambda$ DNA without EcoRI. Although there was some photo-induced DNA cleavage, it was quite different from the case with the enzyme (Fig. 7B).

In contrast, the EcoRI enzyme safely digested tTALE-stained $\lambda$ DNA, as shown in Fig. 7C (SI Movie S5). The kymogram shows enzymatic digestion process. A single $\lambda$ DNA was cut four times out of five recognition sites. It is worthwhile to compare Movie S4 (YOYO-1) and Movie S5 (tTALE-FP). Both movies used EcoRI, which should generate $3.5 \mathrm{~kb}(3.5 \mathrm{kbp} \times 0.34 \mathrm{~nm}=1.2 \mu \mathrm{m})$ of tethered DNA after full digestion. The last image of Movie S5 shows a bunch of $3.5 \mathrm{~kb}$ DNA molecules, but that of Movie S4 does not show them, which implies that there was not proper digestion of YOYO-1 stained DNA. In conclusion, this comparison demonstrates the use of tTALE-FP staining for monitoring enzymatic reactions.

From the molecular images of Fig. 7C, it is notable that there are consistent discrepancies between the expected and observed sites. This phenomenon origins from the fact that the smaller fragments stretched less than large ones compared with the expected lengths. A previous study explained this shortening for tethered DNA at one end in a shear flow ${ }^{54}$. DNA stretch $(X / L)$ reduces with the molecular size $(N)$, as shown in Eq. $(2)^{55}$. Therefore, the smaller DNA makes the stretch $(X / L)$ shorter with the same flow with the constant $C$.

$$
X / L=1-C / N^{5 / 9}
$$

Restriction-enzyme reaction confirmed by AT-specific map. Finally, we combined DNA digestion and post-staining with a $\mathrm{NaCl}$ buffer, as shown in Fig. 8. After the $\mathrm{XbaI}$ reaction, fresh $2 \mathrm{nM}$ tTALE-FP 

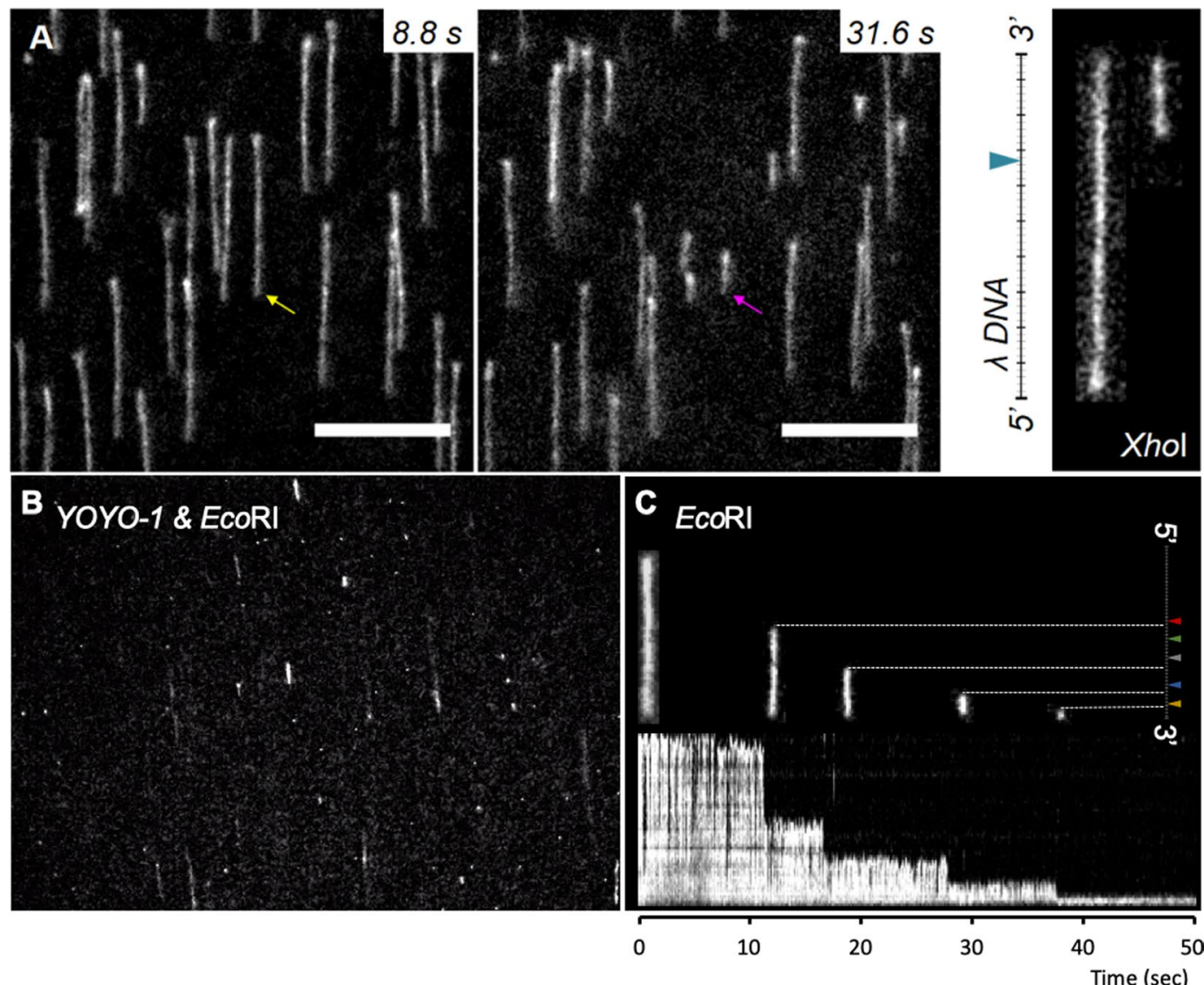

Figure 7. Real-time monitoring of restriction enzyme reaction with tTALE-FP and YOYO-1. (A) XhoI digestion of tTALE-FP $(2 \mathrm{nM})$ stained $\lambda$ DNA (Scale bars $=10 \mu \mathrm{m})$ (see Movie S3). (B) EcoRI digestion of YOYO-1 stained DNA as a control (see Movie S4). (C) Kymogram of tTALE-FP stained $\lambda$ DNA digested by EcoRI: four consecutive cutting of a single $\lambda$ DNA (see Movie S5). Five DNA images represent a DNA molecule cut by EcoRI at four out of five target sites.

mixed with $60 \mathrm{mM} \mathrm{NaCl}$ solution flowed through the flow cell. Figure $8 \mathrm{~B}$ illustrates sequence-specifically labeled DNA, which allowed us to confirm the site of the restriction enzyme digestion by comparing the result with the AT-specific consensus $\lambda$ genome pattern that we obtained in Fig. $4 \mathrm{~B}$.

\section{Conclusion}

In this study, we developed tTALE-FP as a salt-tolerant FP-DBP. Unlike other FP-DBPs, tTALE-FP is compatible with staining at elevated salt concentrations $(40-100 \mathrm{mM} \mathrm{NaCl})$, depending on the AT-content to which it binds preferentially. On the other hand, its preference for binding AT-rich regions can be helpful in certain conditions, e.g., to determine the DNA orientation. We also demonstrate that its DNA binding interferes little with the activity of DNA-processing proteins such as DNA restriction enzymes. The likely reason is that it seems to not substantially alter the DNA conformation, as opposed to, e.g., intercalators such as YOYO-1. Finally, it has an additional advantage over intercalators in that it does not induce photo-nicking or photo-cleavage of the DNA.

\section{Material and Methods}

Chemicals. All DNA primers were purchased from Cosmogenetech (Seoul, Korea). The DNA ladder and biotin-labeled DNA oligomer were purchased from Bioneer (Daejeon, Korea). The $\lambda$ DNA (48.5 kb) and all enzymes were purchased from New England Biolabs (Ipswich, MA). T4 GT7 DNA $(165,644 \mathrm{bp})$ was purchased from Nippon Gene (Tokyo, Japan). The TALEN plasmids (RHD_Exon4_TALEN_L) were obtained from Yonsei University College of Medicine (Seoul, Korea). The AccuPower ${ }^{\circledR}$ Pfu PCR PreMix kit was purchased from Bioneer (Daejeon, Korea). The E. coli strains DH5 $\alpha$ and BL21 (DE3) were purchased from Yeastern (Taipei, Taiwan). Epoxy was obtained from Devcon (Riviera Beach, FL). N-trimethoxymethyl silyl propyl-N,N,N-trimethyl ammonium chloride in 50\% methanol was purchased from Gelest (Morrisville, PA), and N-[3-(trimethoxysilyl)propyl] ethylene diamine was purchased from Sigma (St. Louis, MO). mPEG-succinimidyl valerate and biotin-PEG-succinimidyl carbonate (both MW 5000) were purchased from Laysan Bio (Arab, AL). Ni-NTA agarose resin and the disposable empty gravity column were purchased from Qiagen (Venlo, Netherlands). All other chemicals were obtained from Sigma-Aldrich (St. Louis, MO). 
A
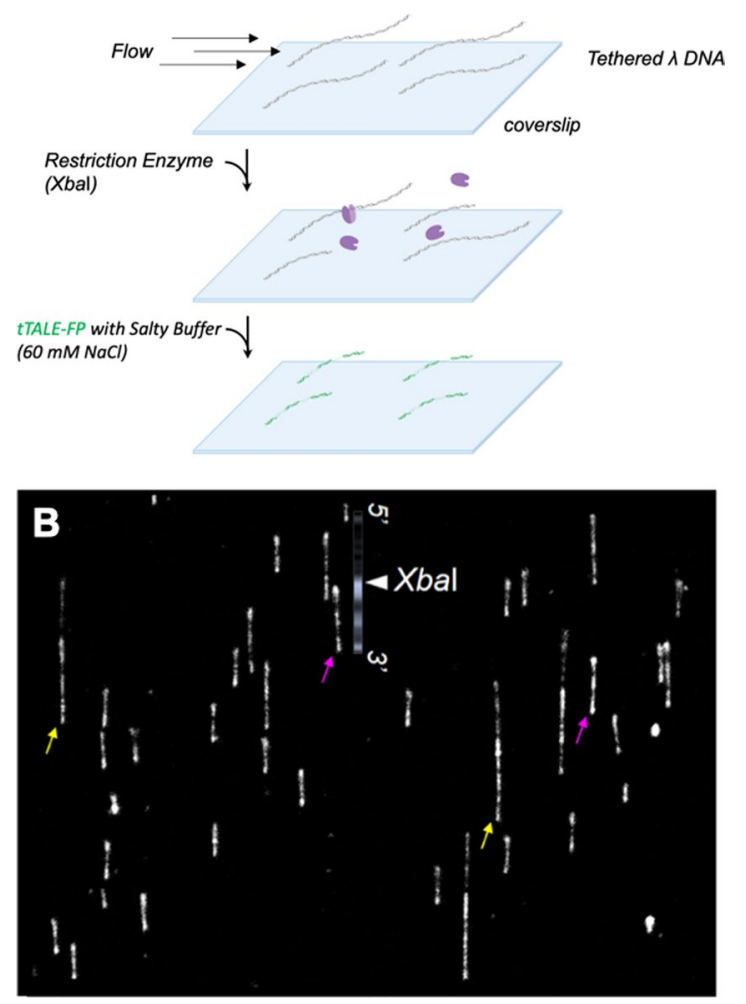

Figure 8. DNA digestion and confirmation by the optical map. (A) Schematic of $X b a$ I digested $\lambda$ DNA patterned with tTALE-FP $(2 \mathrm{nM})$ to reveal the genome-specific pattern (made in @BioRender - biorender.com). (B) $\lambda$ DNA in a mixture of tTALE-FP and NaCl solution. Yellow arrows indicate whole $\lambda$ DNA and pink arrows indicate digested $\lambda$ DNA, compared with AT-specific consensus genomic map.

Microscopy. The microscopy system comprised an inverted microscope (Olympus IX70, Tokyo, Japan) equipped with $60 \times$ and $100 \times$ Olympus UPlanSApo oil immersion objectives and an illuminated LED light source (SOLA SM II light engine, Lumencor, Beaverton, OR). The light passed through the corresponding filter sets (Semrock, Rochester, NY) for excitation and emission of light. Fluorescence images were captured using a scientific complementary metal-oxide-semiconductor (sCMOS) camera (PRIME; Photometrics, AZ, USA) with $100 \mathrm{~ms}$ exposure time and images were stored as 16-bit TIFF file using Micro-manager. ImageJ was utilized for image processing using a Java plug-in developed in our laboratory for image analysis. Python programs were used to compare the fluorescence intensity of two DNA images.

tTALE-FP construction, purification, and cell growth. The plasmid pET-15b (Novagen, Germany) was used to construct the recombinants and express tTALE-FP. The fluorescent protein part and TALE part were amplified and fused by a linker sequence ( $5^{\prime}$-CTT GTA CAG CTC GTC CAT GCC-3') through a typical overlap PCR process. For the fluorescent protein (EGFP) part, a forward primer (5'- GGC GGC TCT GGC GGC ATG GTG AGC AAG GGC GAG G - $3^{\prime}$ ) and reverse primer (5' - ATT TCA GGA TCC TTA CGC CTT GTA CAG CTC GTC CAT G - $3^{\prime}$ ) were used in $20 \mu \mathrm{L}$ of $P f u$ PCR PreMix supplemented with $0.25 \mathrm{mM}$ of each dNTP and $1.5 \mathrm{mM}$ $\mathrm{MgCl}_{2}$. For the TALE part, the TALEN plasmid was isolated from $R H D$ _Exon4_TALEN_L $\mathrm{L}^{41}$. A forward primer (5'- ATT TCA CAT ATG GAT CTA CGC ACG CTC GGC TAC - $3^{\prime}$ ) and reverse primer (5'- CAC CAT GCC GCC AGA GCC GCC TTC ACT TTT GAC TAG CAA CGC GGC - $3^{\prime}$ ) were used as described above. The fluorescent protein part and the TALE part were fused by the mediating linker site. This PCR process was performed by incubation at $95^{\circ} \mathrm{C}$ for $2 \mathrm{~min}, 94^{\circ} \mathrm{C}$ for $1 \mathrm{~min}, 55^{\circ} \mathrm{C}$ for $1 \mathrm{~min}$, and $72^{\circ} \mathrm{C}$ for approximately $4 \mathrm{~min}$ for 12 cycles. After constructing the tTALE-FP templates, an overlap PCR was performed with a forward primer (5'- ATT TCA CAT ATG GAT CTA CGC ACG CTC - $3^{\prime}$ ) and reverse primer (5'- ATT TCA GGA TCC TTA CGC CTT GTA CAG CTC $\left.-3^{\prime}, \mathrm{N}^{\prime}-t T A L E-F P-\mathrm{C}^{\prime}\right)$. Except for the tTALE-FP template construction step, all PCR analyses were performed by incubation at $95^{\circ} \mathrm{C}$ for $2 \mathrm{~min}, 94^{\circ} \mathrm{C}$ for $1 \mathrm{~min}, 55^{\circ} \mathrm{C}$ for $1 \mathrm{~min}$ and $72^{\circ} \mathrm{C}$ for approximately $4 \mathrm{~min}$ for 35 cycles. After the purification of the PCR products, NdeI and BamHI were used for the fragment insertion into the pET-15b vector. The ligation reaction was performed for $1 \mathrm{hr}$ at $16^{\circ} \mathrm{C}$.

The recombinant tTALE-FP plasmids were transformed into E. coli DH5 $\alpha$ strains using the heat shock method, and the DH5 $\alpha$ transformation was assessed by colony PCR. For the protein over-expression, the plasmids were purified and transformed into the E. coli BL21 (DE3) strains. The transformed cells were recovered in fresh LB media without ampicillin for $1 \mathrm{hr}$ and spread evenly on an LB agar plate with ampicillin overnight. A single colony was incubated in fresh LB medium supplemented with ampicillin for $12 \mathrm{hr}$. After saturation, the 
transformed cells were cultured to an optical density of approximately 0.8 at $37^{\circ} \mathrm{C}$ with corresponding antibiotics. The tTALE-FP protein over-expression was induced by a final concentration of $1 \mathrm{mM}$ IPTG overnight on a shaker at $20^{\circ} \mathrm{C}$ and $150 \mathrm{rpm}$. The cells were lysed by ultrasonication for $30 \mathrm{~min}$, and the cell debris was centrifuged at $13,000 \mathrm{rpm}$ for $10 \mathrm{~min}$ at $4^{\circ} \mathrm{C}$. Then, $6 \times$ His-tagged tTALE-FP was purified using affinity chromatography with Ni-NTA agarose resin. The mixture of cell proteins and resin was kept on a shaking platform at $4{ }^{\circ} \mathrm{C}$ for $1 \mathrm{hr}$. The lysate containing proteins bound to Ni-NTA agarose resin was loaded onto the affinity column, washed with protein wash buffer $\left(50 \mathrm{mM} \mathrm{Na}_{2} \mathrm{HPO}_{4}, 300 \mathrm{mM} \mathrm{NaCl}, 20 \mathrm{mM}\right.$ imidazole, $\left.\mathrm{pH} 8.0\right)$ several times, and finally eluted with protein elution buffer $\left(50 \mathrm{mM} \mathrm{Na}_{2} \mathrm{HPO}_{4}, 300 \mathrm{mM} \mathrm{NaCl}, 250 \mathrm{mM}\right.$ imidazole, $\mathrm{pH}$ 8.0). After the SDS-PAGE analysis, further protein purification processes were not performed (Fig. 1C).

Positively charged glass surface preparation. Glass coverslips $(22 \times 22 \mathrm{~mm})$ were stacked in a Teflon rack, immersed in a piranha etching solution $\left(30: 70 \mathrm{v} / \mathrm{v} \mathrm{H}_{2} \mathrm{O}_{2} / \mathrm{H}_{2} \mathrm{SO}_{4}\right)$ for $3 \mathrm{hr}$ and rinsed thoroughly with deionized water. After sonicating the neutralized coverslips for $30 \mathrm{~min}$, two types of derivatized surfaces could be created. Then, $400 \mu \mathrm{L}$ of $\mathrm{N}$-trimethoxymethyl silylpropyl-N,N,N-trimethylammonium chloride in $50 \%$ methanol were added to $250 \mathrm{~mL}$ of deionized water. The glass coverslips were incubated in this solution for $16 \mathrm{hr}$ at $65^{\circ} \mathrm{C}$, followed by rinsing with ethanol to make a positively charged glass surface. These coverslips were used within two weeks of their preparation.

Single DNA molecule imaging. To image the tTALE-FP-stained DNA, the DNA molecules (approximately $15 \mathrm{ng} / \mu \mathrm{L})$ were mixed with tTALE-FP $(2-20 \mathrm{nM})$ in $1 \times$ TE $(10 \mathrm{mM}$ Tris, $1 \mathrm{mM}$ EDTA, $\mathrm{pH} 8.0)$. NaCl salt buffer was prepared by diluting $150 \mathrm{mM} \mathrm{NaCl}$ in $1 \times \mathrm{TE}$ buffer for each concentration. The mixture was incubated at room temperature for $10 \mathrm{~min}$ and then added to a positively charged surface. This coverslip was mounted on a glass slide. After the sample preparation, the DNA molecules were imaged under a microscope.

Fluorescent resonance energy transfer (FRET). Three kinds of $5^{\prime}$-ATTO ${ }^{\mathrm{TM}}$ 590-labeled double-stranded DNA (dsDNA) were prepared by hybridizing $5^{\prime}-\mathrm{ATTO}^{\mathrm{TM}} 590$-labeled single-stranded DNA (ssDNA) and its complementary ssDNA (target DNA: TGTCTGTATG, A/T rich DNA: GAAGAAAATGATCTA, G/C rich DNA: GCGACCTCGCGGGTT). $10 \mu \mathrm{L}$ of every complementary ssDNA molecules $(100 \mu \mathrm{M})$ was mixed with $20 \mu \mathrm{L}$ of $100 \mathrm{mM} \mathrm{NaCl}$. Each mixture was heated at $95^{\circ} \mathrm{C}$ and cooled gradually $\left(0.5^{\circ} \mathrm{C} / \mathrm{min}\right)$ to $20^{\circ} \mathrm{C}$ and stored at $12^{\circ} \mathrm{C}$ to form a duplex. The $5^{\prime}$-ATTO ${ }^{\mathrm{TM}} 590$-labeled dsDNA $(100 \mathrm{nM})$ was incubated with tTALE-eGFP $(300 \mathrm{nM})$ in TE ( $\mathrm{pH} 8.0)$, and fluorescence was scanned from 498 to $750 \mathrm{~nm}$ with excitation at $488 \mathrm{~nm}$. To measure $K_{\mathrm{d}}$, the $5^{\prime}$-ATTO ${ }^{\mathrm{TM}} 590$-labeled dsDNA $(100 \mathrm{nM})$ containing target sequence was titrated with tTALE-eGFP $(10,20,30,50,80$ and $100 \mathrm{nM})$, and fluorescence was measured at $631 \mathrm{~nm}$ with excitation at $488 \mathrm{~nm}$. To investigate the change of fluorescence intensity at $631 \mathrm{~nm}$ with corresponding $\mathrm{NaCl}$ concentration, three different dsDNA $(100 \mathrm{nM})$ and tTALE-eGFP $(30 \mathrm{nM})$ were incubated separately with different $\mathrm{NaCl}$ solutions $(0,10,20$, $40,70,100,150,200 \mathrm{mM})$, and fluorescence was measured at $631 \mathrm{~nm}$ with excitation at $488 \mathrm{~nm}$.

PEGylated glass surface preparation. To obtain surfaces coated with primary amine groups, $2 \mathrm{~mL}$ of $\mathrm{N}$-[3-(trimethoxysilyl)propyl] ethylenediamine and $10 \mathrm{~mL}$ of glacial acetic acid were added to $200 \mathrm{~mL}$ of methanol. The glass coverslips were incubated in this solution for $30 \mathrm{~min}$, sonicated for $15 \mathrm{~min}$, incubated again for $16 \mathrm{hr}$ at room temperature, and rinsed with methanol and ethanol. The aminosilanized glass was coated with PEG. Then, $80 \mathrm{mg}$ of mPEG-succinimidyl valerate and $2 \mathrm{mg}$ of biotin-PEG-succinimidyl carbonate were added to freshly prepared $0.1 \mathrm{M}$ sodium bicarbonate. This solution was completely mixed and briefly centrifuged. In total, $50 \mu \mathrm{L}$ of PEG solution was added to a clean slide glass without air bubbles, covered with aminosilanized glass overnight, and rinsed carefully with water.

DNA-tethering in a flow cell. The flow chamber comprised an acrylic acid resin holder, strips of double-sided tape, epoxy, and a PEGylated coverslip as previously described ${ }^{52}$. The acrylic holder with dimensions of $76 \mathrm{~mm} \times 26 \mathrm{~mm} \times 5 \mathrm{~mm}(\mathrm{~L} \times \mathrm{W} \times \mathrm{H})$, including the inlet and outlet holes, was fabricated with laser cutting. A PEGylated coverslip was placed on the double-sided tape attached to the acrylic holder, and the gaps were filled with epoxy. A yellow pipette tip was installed on an inlet port for a buffer reservoir, and tubing was connected to an outlet port by epoxy bonding that was cured at room temperature for $5 \mathrm{~min}$. The dimensions of the flow chamber were $3 \times 17 \times 0.1 \mathrm{~mm}(\mathrm{~L} \times \mathrm{W} \times \mathrm{H})$. A syringe pump, i.e., NE-1000 (New Era Pump Systems Inc., Wantagh, $\mathrm{NY}$ ), was used to regulate the buffer delivery into the flow cell. After the preparation of the PEGylated surfaces, $25 \mu \mathrm{g} \mathrm{mL}^{-1}$ of NeutrAvidin in a T50 solution $(10 \mathrm{mM}$ Tris, $50 \mathrm{mM} \mathrm{NaCl}, \mathrm{pH} 8.0)$ were loaded and incubated at room temperature for $5 \mathrm{~min}$. One micromolar $\lambda$ DNA overhang oligo (5'-pGGGCGGCGACCT-TEG-biotin-3 ') was loaded into the flow cell and incubated at room temperature for $5 \mathrm{~min}$. The mixture of $\lambda$ DNA, T4 DNA ligase, and reaction buffer were loaded and kept at room temperature for $30 \mathrm{~min}$. After washing the residual enzyme mixture with $1 \times$ TE buffer ( $10 \mathrm{mM}$ Tris, $1 \mathrm{mM}$ EDTA, $\mathrm{pH}$ 8.5), the diluted DNA staining tTALE-FP (approximately $2 \mathrm{nM}$ in $1 \times \mathrm{TE}$ buffer or $\mathrm{NaCl}$ salt buffer) flowed into the chamber and was incubated at room temperature for $5 \mathrm{~min}$. The stained DNA molecules were visualized under a continuous flow of $1 \times \mathrm{TE}$ buffer or $\mathrm{NaCl}$ salt buffer, and the flow rate was maintained at $100 \mu \mathrm{L} \mathrm{min}^{-1}$.

Flow cell with surface-immobilization. The flow chamber comprised an acrylic resin holder (slide glass size: $75 \mathrm{~mm} \times 25 \mathrm{~mm}$ ) and a positively charged cover glass. The acrylic resin holder was treated for 30 seconds in an air plasma generator (Cute Basic, FemtoScience, Suwon, Korea) to make the surface hydrophilic. A positively charged glass surface was placed on the double-sided tape ( $3 \mathrm{M})$ attached to the acrylic holder, and the gaps were filled with epoxy resin. A pipette was used for flushing DNA molecules, proteins, and buffer, as shown in Fig. 3E. 
DNA (1 pM) was loaded into a flow cell, and subsequently, a tTALE-FP solution was flushed to stain. After washing the residual proteins with $1 \times \mathrm{TE}$ solution, DNA was visualized with fluorescence microscopy. A lab-made python program has been used to analyze DNA images (Fig. 3F).

Received: 29 August 2018; Accepted: 5 November 2019;

Published online: 20 November 2019

\section{References}

1. Lee, J., Kim, Y., Lee, S. \& Jo, K. Visualization of large elongated DNA molecules. Electrophoresis 36, 2057-2071, https://doi. org/10.1002/elps.201400479 (2015).

2. Schwartz, D. C. et al. Ordered restriction maps of Saccharomyces cerevisiae chromosomes constructed by optical mapping. Science 262, 110-114 (1993).

3. Jo, K. et al. A single-molecule barcoding system using nanoslits for DNA analysis. Proc Natl Acad Sci USA 104, 2673-2678, https:// doi.org/10.1073/pnas.0611151104 (2007).

4. Gupta, A., Kounovsky-Shafer, K. L., Ravindran, P. \& Schwartz, D. C. Optical mapping and nanocoding approaches to whole-genome analysis. Microfluidics and Nanofluidics 20, https://doi.org/10.1007/s10404-015-1685-y (2016).

5. Kounovsky-Shafer, K. L. et al. Electrostatic confinement and manipulation of DNA molecules for genome analysis. Proc Natl Acad Sci USA, https://doi.org/10.1073/pnas.1711069114 (2017).

6. Lee, S. et al. TAMRA-polypyrrole for A/T sequence visualization on DNA molecules. Nucleic Acids Research, gky531-gky531, https://doi.org/10.1093/nar/gky531 (2018).

7. Perna, N. T. et al. Genome sequence of enterohaemorrhagic Escherichia coli O157:H7. Nature 409, 529-533 (2001).

8. Seo, J. S. et al. De novo assembly and phasing of a Korean human genome. Nature 538, 243-+, https://doi.org/10.1038/nature20098 (2016).

9. Gupta, A. et al. Single-molecule analysis reveals widespread structural variation in multiple myeloma. Proc Natl Acad Sci USA 112, 7689-7694, https://doi.org/10.1073/pnas.1418577112 (2015).

10. Kidd, J. M. et al. Mapping and sequencing of structural variation from eight human genomes. Nature 453, 56-64, https://doi. org/10.1038/Nature06862 (2008).

11. Park, J. et al. Single-molecule DNA visualization using AT-specific red and non-specific green DNA-binding fluorescent proteins. Analyst 144, 921-927, https://doi.org/10.1039/c8an01426d (2019).

12. Nyberg, L. K. et al. Rapid identification of intact bacterial resistance plasmids via optical mapping of single DNA molecules. Sci RepUk 6, https://doi.org/10.1038/srep30410 (2016).

13. Michaeli, Y. et al. Optical detection of epigenetic marks: sensitive quantification and direct imaging of individual hydroxymethylcytosine bases. Chem Commun 49, 8599-8601, https://doi.org/10.1039/c3cc42543f (2013).

14. Levy-Sakin, M. et al. Toward Single-Molecule Optical Mapping of the Epigenome. Acs Nano 8, 14-26, https://doi.org/10.1021/ nn4050694 (2014).

15. Lee, J., Park, H. S., Lim, S. \& Jo, K. Visualization of UV-induced damage on single DNA molecules. Chem. Commun. 49, 4740-4742, https://doi.org/10.1039/C3cc38884k (2013).

16. Zirkin, S. et al. Lighting Up Individual DNA Damage Sites by In Vitro Repair Synthesis. Journal of the American Chemical Society 136, 7771-7776, https://doi.org/10.1021/ja503677n (2014).

17. Lee, J. K. Y., Lim, S. \& Jo, K. Single-Molecule Visualization of ROS-induced DNA Damage in Large DNA Molecules Analyst, https:// doi.org/10.1039/C1035AN01875G (2016).

18. Kang, Y. et al. Analysis of alcohol-induced DNA damage in Escherichia coli by visualizing single genomic DNA molecules. Analyst 141, 4326-4331, https://doi.org/10.1039/c6an00616g (2016).

19. Hamdan, S. M., Loparo, J. J., Takahashi, M., Richardson, C. C. \& van Oijen, A. M. Dynamics of DNA replication loops reveal temporal control of lagging-strand synthesis. Nature 457, 336-U339, https://doi.org/10.1038/nature07512 (2009).

20. Graham, J. E., Marians, K. J. \& Kowalczykowski, S. C. Independent and Stochastic Action of DNA Polymerases in the Replisome. Cell 169, 1201, https://doi.org/10.1016/j.cell.2017.05.041 (2017).

21. Finkelstein, I. J., Visnapuu, M. L. \& Greene, E. C. Single-molecule imaging reveals mechanisms of protein disruption by a DNA translocase. Nature 468, 983-987, https://doi.org/10.1038/nature09561 (2010).

22. Yeom, T. et al. Mass spectrometric investigation of the role of the linking polypeptide chain in DNA polymerase I. Analyst 139, 2432-2439, https://doi.org/10.1039/C4an00107a (2014).

23. Rye, H. S. et al. Stable fluorescent complexes of double-stranded DNA with bis-intercalating asymmetric cyanine dyes: properties and applications. Nucleic acids research 20, 2803-2812 (1992).

24. Biebricher, A. S. et al. The impact of DNA intercalators on DNA and DNA-processing enzymes elucidated through force-dependent binding kinetics. Nat Commun 6, 7304, https://doi.org/10.1038/ncomms8304 (2015).

25. Lee, S. et al. DNA binding fluorescent proteins for the direct visualization of large DNA molecules. Nucleic Acids Res 44, e6, https:// doi.org/10.1093/nar/gkv834 (2016).

26. Tycon, M. A., Dial, C. F., Faison, K., Melvin, W. \& Fecko, C. J. Quantification of dye-mediated photodamage during single-molecule DNA imaging. Anal Biochem 426, 13-21, https://doi.org/10.1016/J.Ab.2012.03.021 (2012).

27. Kundukad, B., Yan, J. \& Doyle, P. S. Effect of YOYO-1 on the mechanical properties of DNA. Soft Matter 10, 9721-9728, https://doi. org/10.1039/c4sm02025a (2014).

28. Smith, S. B., Finzi, L. \& Bustamante, C. Direct Mechanical Measurements of the Elasticity of Single DNA-Molecules by Using Magnetic Beads. Science 258, 1122-1126, https://doi.org/10.1126/science.1439819 (1992).

29. Meng, X., Cai, W. \& Schwartz, D. C. Inhibition of restriction endonuclease activity by DNA binding fluorochromes. J Biomol Struct Dyn 13, 945-951 (1996).

30. Maschmann, A. \& Kounovsky-Shafer, K. L. Determination of restriction enzyme activity when cutting DNA labeled with the TOTO dye family. Nucleosides Nucleotides \& Nucleic Acids 36, 406-417, https://doi.org/10.1080/15257770.2017.1300665 (2017).

31. Maschmann, A. et al. Determining if DNA Stained with a Cyanine Dye Can Be Digested with Restriction Enzymes. Jove-Journal of Visualized Experiments, https://doi.org/10.3791/57141 (2018).

32. Koster, D. A., Palle, K., Bot, E. S. M., Bjornsti, M. A. \& Dekker, N. H. Antitumour drugs impede DNA uncoiling by topoisomerase I. Nature 448, 213-217, https://doi.org/10.1038/nature05938 (2007).

33. Paramanathan, T., Vladescu, I., McCauley, M. J., Rouzina, I. \& Williams, M. C. Force spectroscopy reveals the DNA structural dynamics that govern the slow binding of Actinomycin D. Nucleic Acids Research 40, 4925-4932, https://doi.org/10.1093/nar/gks069 (2012).

34. Lee, S. et al. Investigation of various fluorescent protein-DNA binding peptides for effectively visualizing large DNA. molecules. Rsc Advances 6, 46291-46298, https://doi.org/10.1039/c6ra08683g (2016).

35. Lee, S. \& Jo, K. Visualization of Surface-tethered Large DNA Molecules with a Fluorescent Protein DNA Binding Peptide. JoveJournal of Visualized Experiments, e54141 (2016). 
36. Kim, K. I. et al. DNA Binding Peptide Directed Synthesis of Continuous DNA Nanowires for Analysis of Large DNA Molecules by Scanning Electron Microscope. Small 13 (2017).

37. Zhang, F. et al. Efficient construction of sequence-specific TAL effectors for modulating mammalian transcription. Nat Biotechnol 29, 149-U190, https://doi.org/10.1038/nbt.1775 (2011).

38. Miyanari, Y., Ziegler-Birling, C. \& Torres-Padilla, M. E. Live visualization of chromatin dynamics with fluorescent TALEs. Nat Struct Mol Biol 20, 1321-U1252, https://doi.org/10.1038/nsmb.2680 (2013).

39. Christian, M. et al. Targeting DNA Double-Strand Breaks with TAL Effector Nucleases. Genetics 186, 757-U476, https://doi. org/10.1534/genetics.110.120717 (2010).

40. Terry, C. A., Fernandez, M. J., Gude, L., Lorente, A. \& Grant, K. B. Physiologically Relevant Concentrations of $\mathrm{NaCl}$ and $\mathrm{KCl}$ Increase DNA Photocleavage by an N-Substituted 9-Aminomethylanthracene Dye. Biochemistry 50, 10375-10389, https://doi.org/10.1021/ bi200972c (2011).

41. Kim, Y. H. et al. Rh D blood group conversion using transcription activator-like effector nucleases. Nat Commun 6, https://doi. org/10.1038/ncomms8451 (2015).

42. Scholze, H. \& Boch, J. TAL effectors are remote controls for gene activation. Curr Opin Microbiol 14, 47-53, https://doi.org/10.1016/j. mib.2010.12.001 (2011).

43. Voytas, D. F. \& Joung, J. K. DNA Binding Made Easy. Science 326, 1491-1492, https://doi.org/10.1126/science.1183604 (2009).

44. Moscou, M. J. \& Bogdanove, A. J. A Simple Cipher Governs DNA Recognition by TAL Effectors. Science 326, 1501-1501, https://doi. org/10.1126/science.1178817 (2009).

45. Boch, J. et al. Breaking the Code of DNA Binding Specificity of TAL-Type III Effectors. Science 326, 1509-1512, https://doi. org/10.1126/science.1178811 (2009).

46. Miller, J. C. et al. Improved specificity of TALE-based genome editing using an expanded RVD repertoire. Nat Methods 12, 465-+, https://doi.org/10.1038/nmeth.3330 (2015).

47. Mak, A. N. S., Bradley, P., Cernadas, R. A., Bogdanove, A. J. \& Stoddard, B. L. The Crystal Structure of TAL Effector PthXol Bound to Its DNA Target. Science 335, 716-719, https://doi.org/10.1126/science.1216211 (2012).

48. Gao, H. S., Wu, X. J., Chai, J. J. \& Han, Z. F. Crystal structure of a TALE protein reveals an extended N-terminal DNA binding region. Cell Res 22, 1716-1720, https://doi.org/10.1038/cr.2012.156 (2012).

49. Wang, Q., Shui, B., Kotlikoff, M. I. \& Sondermann, H. Structural Basis for Calcium Sensing by GCaMP2. Structure 16, 1817-1827, https://doi.org/10.1016/j.str.2008.10.008 (2008).

50. Lee, S. et al. Nanochannel-Confined TAMRA-Polypyrrole Stained DNA Stretching by Varying the Ionic Strength from Micromolar to Millimolar Concentrations. Polymers 11, 15 (2019).

51. Park, H. et al. FRET-based analysis of protein-nucleic acid interactions by genetically incorporating a fluorescent amino acid. Amino Acids 47, 729-734, https://doi.org/10.1007/s00726-014-1900-2 (2015).

52. Kim, Y. \& Jo, K. Neutravidin coated surfaces for single DNA molecule analysis. Chem Commun 47, 6248-6250, https://doi. org/10.1039/C0cc05396a (2011)

53. Riehn, R. et al. Restriction mapping in nanofluidic devices. Proc Natl Acad Sci USA 102, 10012-10016 (2005).

54. Dimalanta, E. T. et al. A microfluidic system for large DNA molecule arrays. Anal Chem 76, 5293-5301 (2004).

55. Ladoux, B. \& Doyle, P. S. Stretching tethered DNA chains in shear flow. Europhysics Letters 52, 511-517 (2000).

\section{Acknowledgements}

We thank Prof. HyeongBeom Kim for providing the plasmid containing the TALEN gene. This work was supported by the Nuclear R\&D program and a National Research Foundation of Korea (NRF) grant [NRF2017R1A2B2012665, NRF-2016M3A9B6947831 \& NRF-2016R1A6A1A03012845].

\section{Author contributions}

E.S., H.S.L. and K.J. designed research; E.S., W.K. S.L., J.B., S.K. and W.K. performed research; S.L., H.S., S.L., S.K. contributed new reagents/analytic tools; E.S., W.K., S.L. and K.J. analyzed data; and E.S., W.K., H.S.L. and K.J. wrote the paper.

\section{Competing interests}

The authors declare no competing interests.

\section{Additional information}

Supplementary information is available for this paper at https://doi.org/10.1038/s41598-019-53722-0.

Correspondence and requests for materials should be addressed to H.S.L. or K.J.

Reprints and permissions information is available at www.nature.com/reprints.

Publisher's note Springer Nature remains neutral with regard to jurisdictional claims in published maps and institutional affiliations.

Open Access This article is licensed under a Creative Commons Attribution 4.0 International License, which permits use, sharing, adaptation, distribution and reproduction in any medium or format, as long as you give appropriate credit to the original author(s) and the source, provide a link to the Creative Commons license, and indicate if changes were made. The images or other third party material in this article are included in the article's Creative Commons license, unless indicated otherwise in a credit line to the material. If material is not included in the article's Creative Commons license and your intended use is not permitted by statutory regulation or exceeds the permitted use, you will need to obtain permission directly from the copyright holder. To view a copy of this license, visit http://creativecommons.org/licenses/by/4.0/.

(C) The Author(s) 2019 